\title{
Remediation of salt and boron-affected soil by addition of organic matter: an investigation into improving tomato plant productivity
}

\author{
Remediación a la sal y boro que afecta al suelo, mediante la adición de materia \\ orgánica: una investigación para mejorar la productividad de plantas de tomate
}

\author{
Wladimir Esteban ${ }^{1}$, Patricia Pacheco ${ }^{1}$, Luis Tapia1 ${ }^{1}$ Elizabeth Bastías ${ }^{1 *}$
}

\begin{abstract}
To mitigate the effect of salt stress and excess B in soil and consequently increase crop yield and improve the behaviour of cv. "Poncho Negro" there are low-cost strategies such as the application of organic amendments. This study aimed at remediating excess salt $(150 \mathrm{mM} \mathrm{NaCl})$ and $\mathrm{B}\left(20 \mathrm{mg} \mathrm{L}^{-1} \mathrm{~B}\right)$ in soil using organic matter treatment $(4 \%$ and $6 \%)$. Stress was supplied by irrigation. The rate of net $\mathrm{CO}_{2}$ assimilation, $\mathrm{B}, \mathrm{Na}^{+}, \mathrm{K}$ and $\mathrm{Ca}^{2+}$ content, soluble sugars and proline were measured. All growth parameters measured were higher with $6 \%$ organic matter $(\mathrm{OM})$ in soil than with $4 \% \mathrm{OM}$, including salinity treatments and excessive $\mathrm{B}$, while $\mathrm{Na}^{+}$and $\mathrm{B}$ concentrations were reduced in leaves and roots. The photosynthesis rate was maintained at the level of control plants with $6 \%$ OM applied in soil in treatments with salinity alone and with excess B. In the salinity alone treatment there was a marked increase in the content of compatible solutes, but with the application of $6 \%$ OM their content was reduced by more than $100 \%$. The remediation of salt and boron-affected soil by addition of organic matter $(6 \%)$ is an effective way to improve the behaviour of tomato.
\end{abstract}

Key words: organic matter, boric acid, salinity, Solanum lycopersicum L.

\section{RESUMEN}

Para mitigar el efecto del estrés de sal y exceso B en el suelo y, consecuentemente, aumentar y mejorar el comportamiento de cv. de tomate "Poncho Negro", como una estrategia de bajo costo como es la aplicación de enmiendas orgánicas. Este estudio tuvo como objetivo remediar el exceso de sal $(\mathrm{NaCl} 150 \mathrm{mM})$ y B $\left(20 \mathrm{mg} \mathrm{L}^{-1} \mathrm{~B}\right)$ en el suelo mediante el tratamiento de aplicación de materia orgánica (4\% y $6 \%$ M.O.). El estrés fue suministrado por el riego. La tasa de asimilación neta de $\mathrm{CO}_{2}$, contenido de $\mathrm{B}$, $\mathrm{Na}^{+}, \mathrm{K}^{+}$y $\mathrm{Ca}^{2}$, los azúcares solubles y prolina fueron medidos. Todos los parámetros de crecimiento medidos fueron mayores con 6\% O.M. en el suelo que con $4 \%$ de M.O., incluyendo los tratamientos de salinidad y excesivo B, mientras que las concentraciones de $\mathrm{Na}^{+}$y $\mathrm{B}$ se redujeron en hojas y raíces. La tasa de fotosíntesis se mantuvo a nivel de las plantas de control con $6 \%$ de M.O. aplicada en el suelo en los tratamientos con salinidad sola y con exceso de B. En el tratamiento de solo salinidad hubo un marcado incremento en el contenido de solutos compatibles, pero con la aplicación de 6\% de M.O. su contenido se redujo en más de el 100\%. La remediación en el suelo afectado por exceso de sal y B en la adición de materia orgánica (6\%) es una forma efectiva para mejorar el comportamiento del tomate.

Palabras clave: materia orgánica, ácido bórico, salinidad, Solanum lycopersicum $L$.

\section{Introduction}

Salinity is a major adverse environmental constraint for plant productivity, limiting the utilization of about 800 million ha of agricultural land globally (Yang et al., 2011). Salinization of agricultural soils is a worldwide concern, especially in irrigated land. Saline soil is characterized by the presence of toxic levels of sodium and its chlorides and sulphates (Rajaravindran and Natarajan, 2012).
Salt induces osmotic stress by limiting absorption of water from soil, and ionic stress results from high concentrations of potentially toxic salt ions within plant cells. Plants have evolved a variety of protective mechanisms that allow survival and growth under these unfavourable environmental conditions, including the accumulation of ions and osmolytes such as proline (Maggio et al., 2010; Rajaravindran and Natarajan, 2012). Boron (B) is likely the micronutrient whose concentration within

\footnotetext{
1 Departamento de Producción Agrícola, Centro de Agricultura y Biodiversidad del Desierto (CAyBIDE), Facultad de Ciencias Agronómicas. Universidad de Tarapacá, Arica, Chile.

* Corresponding author: ebastias@uta.cl
}

Fecha de Recepción: 16 Diciembre, 2015.

Fecha de Aceptación: 28 Marzo, 2016. 
vascular plants must be kept within the narrowest range to achieve optimal growth; for this reason excess B in soils is more difficult to manage than its deficiency (Herrera-Rodríguez et al., 2010). Boron toxicity is an agricultural problem that reduces crop yield (Bonilla and González-Fontes, 2011). Irrigation with saline groundwater containing high B concentrations occurs worldwide, with notable examples found in several areas; Israel, USA, Canada and Chile (Díaz et al., 2011). The mechanics of the relationship between B and salinity are not yet elucidated. Nevertheless, the palliative effect of B under saline conditions may be due to an improvement in the functionality of aquaporin, which prevents salt-induced nutrient imbalance, interaction between $\mathrm{B}$ and $\mathrm{Ca}^{2+}$ with respect to cell wall stability and lower $\mathrm{Cl}^{-}$uptake (Bastías et al., 2004a; Bonilla and González-Fontes, 2011). Salinity and B toxicity often occur simultaneously and have interactive effects on plant responses. An alleviating effect of the combined stress on toxic ion concentrations has been confirmed, which did not prevent additive growth reductions (Masood et al., 2012). Excess $\mathrm{B}$ could alter the structure of primary metabolic compounds through binding to ATP, NADH and NADHP, and high internal B concentrations may affect plant development negatively by binding to the ribose of RNA (Reid et al., 2004).

A need exists for low-cost, efficient treatment strategies to reduce the salt toxicity of soils and to improve soil properties, such as the application organic amendments (Shaaban et al., 2013). The physical, chemical and biological properties of salt-affected soil are improved by application of organic matter (OM), leading to enhanced plant growth and development by accelerating the exchange of cations in soil solids and leaching of salts from the root zone (Clark et al., 2007), hence preventing salt injuries and allowing roots to grow more uniformly. The decaying organic matter increases soil $\mathrm{CO}_{2}$ concentration, releases $\mathrm{H}^{+}$, enhances $\mathrm{CaCO}_{3}$ dissolution and liberates more calcium for sodium exchange (Ghaffor et al., 2008). Therefore the application of OM for soil remediation is important for sustainable land use and crop productivity (Wong et al., 2009; Cha-um and Kirdmanee, 2011). Boron uptake by plants is controlled by the $\mathrm{B}$ level in soil solution rather than the total B content in soil. The affinity of OM for B can affect $B$ uptake by plants because of changing $\mathrm{B}$ concentration in the soil solution, which has a prominent effect in reducing B uptake by plants. Boron uptake by plants is expected to decrease as the OM content in the soil increases (Yermiyahu et al., 2001).

Tomato is one of the most important fleshy fruit vegetables with high economic value in the world. Its global production has been increasing and is now over 145 million tons according to the Food and Agriculture Organization of the United Nations. The tomato production area is expected to expand; however, the sensitivity of tomato to environmental stress restricts the production area (Uozumi et al., 2012). Salt stress has been shown to decrease dry matter production, nitrogen uptake, low dry matter, fruit weight and relative water content (Al-Rawahy et al., 1990; Tuna et al., 2007). One study also observed significant reduction in the photosynthetic pigments and total soluble protein (Doganler et al., 2010).

In this study we use the tomato (Solanum lycopersicum L.) variety called "Poncho Negro" grown by farmers of the Lluta valley (northern Chile), which represents an important source of genetic resources of agricultural interest, because it has managed to thrive at levels of salinity and excess B that other varieties of tomato cannot tolerate (Bastías et al., 2010). Under salinity these plants increased their turgor, possibly due to a decrease in leaf water potential through the reduction in the leaf osmotic potential by accumulation of soluble sugars and proline (Contreras et al., 2011); the interaction of $\mathrm{B}$ and salinity reduced the movement of $\mathrm{Na}^{+}$to the leaves by accumulating more leaf $\mathrm{B}$ (Díaz et al., 2011).

In order to find a solution to the effect of salt stress and excess B in soil and consequently increase crop yield, we evaluated the ability of OM to retain excess salts and $\mathrm{B}$ and hence to improve the behaviour of the Poncho Negro variety.

\section{Materials and Methods}

\section{Plant material and culture conditions}

The experiment was conducted in an environmentally controlled greenhouse with day/ night temperatures of $28 / 18^{\circ} \mathrm{C}$, day/night relative humidity of $45 / 85 \%$ and a $16-\mathrm{h}$ photoperiod. Seeds of Solanum lycopersicum L. cv. "Poncho Negro" were planted after germination into individual pots $(1.8 \mathrm{~L})$ containing medium mixture and arranged in 
a randomized complete block experimental design. The soil was collected from an uncultivated field in the Lluta Valley of Chile and the OM used was mature compost. The total amounts of OM added in the mixture were $4 \%$ and $6 \%$. Soil mixture characteristics obtained from the saturated paste are shown in Table 1. Pots were irrigated every 2 $\mathrm{d}$ in order to maintain soil water at field capacity. Chemical fertilizer (Ultrasol crecimiento; 25:10:10) was applied along with Hoagland's solution. The solution was prepared using de-ionized water and the $\mathrm{pH}$, osmotic potential, and conductivity were monitored each week. During the first fifteen days after germination plants were irrigated with the nutrient solution. Subsequently, when the third leaf was fully expanded the plants were exposed to salinity and excess B for $30 \mathrm{~d}$. The control treatments consisted of basic nutrient solution without salt (NaCl-0) or excess boron (B-0) and $4 \%$ or $6 \% \mathrm{OM}$. This basic nutrient solution was supplemented with $150 \mathrm{mM} \mathrm{NaCl}$. An excess of $\mathrm{B}$ in the form of $\mathrm{H}_{3} \mathrm{BO}_{3}$ was added to nutrient solutions to obtain concentrations of $20 \mathrm{mg} \mathrm{L}^{-1}$ of B. Physiological measurements and plant harvest were performed on the 30th day of treatment. Measurements and harvest were performed in the middle of the light period. The photon flux density was $400-500 \mu \mathrm{E} \mathrm{m}^{-2} \mathrm{~s}^{-1}$.

\section{Growth parameters}

At the end of the experimental period, the following growth parameters were determined:

Table 1. Chemical analysis of soil of the different treatments performed at remediation procedures.

\begin{tabular}{lrrr}
\hline Parameter & 2\% O.M. & 4\% O.M. & $6 \%$ O.M. \\
\hline $\mathrm{pH}$ & 5.66 & 6.49 & 5.92 \\
$\mathrm{Ce} \mathrm{mS} / \mathrm{cm} \mathrm{a} 25^{\circ} \mathrm{C}$ & 41.10 & 15.66 & 12.38 \\
$\mathrm{~N}$-disp mg/Kg & 45.17 & 151.26 & 899.15 \\
P-disp mg/Kg & 22.97 & 134.78 & 27.07 \\
K-disp mg/Kg & $1,224.00$ & $1,354.00$ & $1,300.00$ \\
O.M.\% & $\mathbf{2 . 2 2}$ & $\mathbf{4 . 0 9}$ & $\mathbf{5 . 9 6}$ \\
Calcium $\left(\mathrm{Ca}^{2+}\right) \mathrm{mg} / \mathrm{L}$ & $1,991.00$ & $1,008.00$ & $2,596.00$ \\
Magnesium $\left(\mathrm{Mg}^{2+}\right) \mathrm{mg} / \mathrm{L}$ & 279.89 & 429.00 & 74.78 \\
Sodium $\left(\mathrm{Na}^{+}\right) \mathrm{mg} / \mathrm{L}$ & $6,541.00$ & $1,627.17$ & 491.00 \\
Potassium $\left(\mathrm{K}^{+}\right) \mathrm{mg} / \mathrm{L}$ & 215.50 & 65.29 & 53.68 \\
Chloride $\left(\mathrm{Cl}^{-}\right) \mathrm{mg} / \mathrm{L}$ & $15,939.00$ & $4,137.50$ & $2,804.50$ \\
Sulphate $\left(\mathrm{SO}_{4}^{-2}\right) \mathrm{mg} / \mathrm{L}$ & $1,671.70$ & $2,556.60$ & $2,066.04$ \\
Soluble boron $(\mathrm{B}) \mathrm{mg} / \mathrm{L}$ & 17.27 & 24.81 & 22.89 \\
\hline
\end{tabular}

* The results were performed on saturated extract. plant dry weight; total (g), stems, leaves and root; and root/shoot ratio.

\section{Net $\mathrm{CO}_{2}$ assimilation rate}

The gas exchange parameter net $\mathrm{CO}_{2}$ assimilation rate were measured on fully expanded leaves from 11:00 to 13:00 $\mathrm{h}$, using a portable photosynthesis system LI-6400 (Licor Inc., Lincoln, NE, USA) with an infrared gas analyser (IRGA). The measurements were carried out at relative humidity $45-60 \%$ and temperature $20-27^{\circ} \mathrm{C}$ in the greenhouse.

\section{Proline content}

The proline content of salt-stressed and control plants was determined using the method of Bates et al. (1973). Proline was extracted from leaf samples (20 mg FW) according to Weimberg (1987), with minor modifications. For proline measurement, reaction with ninhydrin was carried out and the absorbance was read at $520 \mathrm{~nm}$, using toluene as a blank. The proline concentration was determined

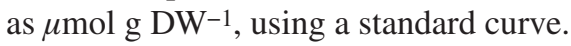

\section{Soluble sugar content}

Soluble sugars were extracted with $80 \%$ ethanol from $20 \mathrm{mg}$ FW and determined colorimetrically at $625 \mathrm{~nm}$ using the anthrone method (Irigoyen et al., 1992).

\section{Ion analysis}

Leaves were separated from stems and roots, rinsed for $15 \mathrm{~s}$ with deionized water, dried at $60^{\circ} \mathrm{C}$ and ground. The dried tissue was weighed, ground and stored in a desiccator. The plant tissues were dry-ashed in a muffle furnace at $500{ }^{\circ} \mathrm{C}$ for $6 \mathrm{~h}$, digested with sulphuric acid and peroxide, and their $\mathrm{K}^{+}, \mathrm{Ca}^{2+}$, and $\mathrm{Na}^{+}$contents determined with a flame photometer (model PFP7, Jenway, Stone, UK). Boron was determined in the dry ash using the Azomethine-H method (Matt et al., 1975).

\section{Data analysis}

All experiments described were repeated three times independently with six replications each time. A completely randomized design was used. The 
experimental data were analysed by ANOVA and the differences were compared by employing the Duncan test with a significance of $p<0.05$ using the SPSS software (SPSS version 15.0, 2006).

\section{Results}

At the end of the treatment salinity alone significantly reduced the whole plant, leaf, stem and root biomass by about $57 \%$ with $4 \%$ OM applied to the soil compared to the control, while $6 \%$ OM reduced these values by almost $40 \%$. All measured parameters were sustained better with $6 \% \mathrm{OM}$ in the soil than with $4 \% \mathrm{OM}$ (Table 2). Plants treated with $\mathrm{B}+\mathrm{NaCl}$ reduced biomass less than plants treated with $\mathrm{NaCl}$ alone, both with $4 \%$ and $6 \% \mathrm{OM}$ in soil. In contrast, with the application of $\mathrm{B}$ under $\mathrm{NaCl}-\mathrm{O}$ conditions and 6\% OM in soil, total plant dry weight was maintained to a greater degree $(60 \%)$ than in plants grown with $4 \% \mathrm{OM}$ and salinity. The root-to-shoot ratio was affected by treatment with salinity, but this ratio was reduced less with 6\% OM (Table 2). In plants treated with $\mathrm{B}+\mathrm{NaCl}$ and soil $6 \% \mathrm{OM}$ the ratio was significantly greater than with $4 \% \mathrm{OM}$.

The net assimilation rate $(A)$, a sensitive parameter, showed no significant differences between control and plants treated with B and salinity with $6 \% \mathrm{OM}$ in soil; in the plants treated with $\mathrm{B}+\mathrm{NaCl} A$ decreased by about $18 \%$ of OM. In contrast, plants subjected to salinity and excess $\mathrm{B}$ in $4 \%$ OM reduced $A$ drastically (Figure 1a). Chlorophyll content in plants also decreased with excess B and salinity with both OM treatments, although the net photosynthetic rate was not affected (Figure 1b).

The soluble sugar content in the plants grown without salinity and with OM treatment in soil showed similar values; in contrast, with salinity only and $4 \%$ OM soluble sugar content increased significantly compared to the control. This behaviour was not observed in soil with $6 \%$ OM. However, the soluble sugar content in plants treated $\mathrm{B}+\mathrm{NaCl}$ with both OM treatments was markedly lower (Figure 1c).

The proline content presented similar behaviour to soluble sugar content; plants with salinity only and $4 \%$ OM significantly increased proline content by up to 4 -fold compared to the control. The proline content in plants treated with $\mathrm{B}+\mathrm{NaCl}$ in both OM treatments was higher than the control. It is important to note that with $6 \% \mathrm{OM}$ the proline level was lower under salinity alone, an effect that should be expected (Figure 1d).

The $\mathrm{Na}^{+}$concentration in leaves (Table 3 ) was increased 5-fold by $\mathrm{OM}$ application in both $\mathrm{NaCl}$ and $\mathrm{NaCl}+\mathrm{B}$ treatments; values were more or less similar in these treatments. The $\mathrm{Na}^{+}$content in roots was increased 3-fold in both $\mathrm{NaCl}$ and $\mathrm{NaCl}$ $+\mathrm{B}$ treatments by $\mathrm{OM}$ application; the application of $6 \% \mathrm{OM}$ to soil reduced $\mathrm{Na}^{+}$content in roots by almost $33 \%$. Similar behaviour was observed in stems (data not shown), but the $\mathrm{Na}^{+}$reduction was more drastic $(72 \%)$. The highest B content was in leaves under $\mathrm{B}$ conditions; with $6 \% \mathrm{OM}$ in soil the B content decreased in all treatments by almost $22 \%$. The B content was lower in roots than in leaves, but B content was reduced about $55 \%$ with the application of $6 \% \mathrm{OM}$ to the soil in saline

Table 2. Effects of organic matter (O.M.) in individual and combined treatments of $150 \mathrm{mM} \mathrm{NaCl}$ and B excess $\left(20 \mathrm{mg} \mathrm{L}^{-1}\right)$ on leaf dry weight ( $\mathrm{g}^{-1}$ plant), stem dry weight $\left(\mathrm{g}^{-1}\right.$ plant $)$, root dry weight $\left(\mathrm{g}^{-1}\right.$ plant) and root-shoot ratio in tomato plants. Values represent the mean of six samples \pm SE. Values in a column with the same letter are not significantly different according to the LSD at $\mathrm{P}<0.05$ using Duncan's multiple-range test.

\begin{tabular}{|c|c|c|c|c|c|c|}
\hline \multirow{2}{*}{ Treatment } & \multirow{2}{*}{ Remediation } & \multicolumn{5}{|c|}{ ( $\mathrm{g}^{-1}$ plant dry weight $)$} \\
\hline & & Leaves & Stems & Roots & Total dry wt & Relation root/shoot \\
\hline \multirow{2}{*}{ Control } & $4 \%$ O.M. & $5.47 \mathrm{~d}$ & $2.55 \mathrm{~d}$ & $1.16 \mathrm{c}$ & $9.18 \mathrm{~d}$ & $0.14 \mathrm{c}$ \\
\hline & $6 \%$ O.M. & $6.95 \mathrm{e}$ & $3.23 \mathrm{e}$ & $2.74 \mathrm{e}$ & $12.92 \mathrm{e}$ & $0.27 \mathrm{~d}$ \\
\hline \multirow{2}{*}{ B20 } & 4\% O.M. & $5.40 \mathrm{~d}$ & $2.63 \mathrm{~d}$ & $0.86 \mathrm{~b}$ & $8.89 \mathrm{~d}$ & $0.11 \mathrm{ab}$ \\
\hline & $6 \%$ O.M. & $8.10 \mathrm{f}$ & $3.54 \mathrm{f}$ & $1,58 \mathrm{~d}$ & $13.22 \mathrm{e}$ & $0.14 \mathrm{c}$ \\
\hline \multirow{2}{*}{$150 \mathrm{mM} \mathrm{NaCl}$} & 4\% O.M. & $2.61 \mathrm{a}$ & $1.08 \mathrm{a}$ & $0.38 \mathrm{a}$ & $4.06 \mathrm{a}$ & $0.10 \mathrm{ab}$ \\
\hline & $6 \%$ O.M. & $4.45 \mathrm{c}$ & $2.14 \mathrm{c}$ & $0.86 \mathrm{~b}$ & $7.45 \mathrm{c}$ & $0.13 b c$ \\
\hline \multirow{2}{*}{$\mathrm{B} 20+150 \mathrm{mM} \mathrm{NaCl}$} & 4\% O.M. & $3.53 \mathrm{~b}$ & $1.80 \mathrm{~b}$ & $0.47 \mathrm{a}$ & $5.72 \mathrm{~b}$ & $0.09 \mathrm{a}$ \\
\hline & $6 \%$ O.M. & $3.72 \mathrm{~b}$ & $2.49 \mathrm{~d}$ & $0.92 \mathrm{~b}$ & $7.01 \mathrm{c}$ & $0.15 \mathrm{c}$ \\
\hline
\end{tabular}



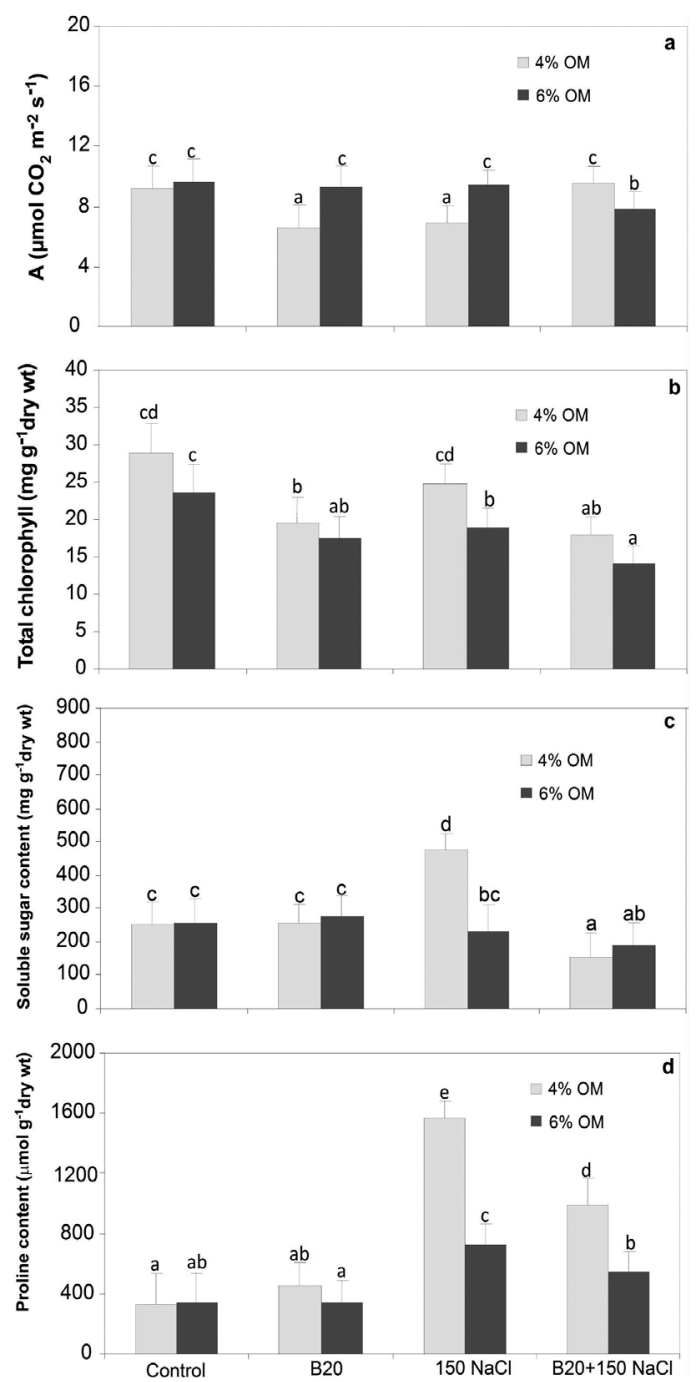

Figure 1. Effects of organic matter $(\mathrm{OM})$ in individual and combined treatments of $150 \mathrm{mM} \mathrm{NaCl}$ and B excess $(20 \mathrm{mg}$ $\mathrm{L}^{-1}$ ) in in tomato plants: (a) net photosynthetic rate; b) total chlorophyll; c) soluble sugar content and d) proline content. Values represent the mean of six samples \pm SE. Bars with the same letter are not significantly different according to the LSD at $\mathrm{P}<0.05$ using Duncan's multiple-range test.

condition. The $\mathrm{K}^{+}$and $\mathrm{Ca}^{2+}$ concentrations were 2-3 times higher in leaves than in roots, showing a tendency to increase with the application of $6 \%$ OM. In contrast, in roots with $6 \%$ OM there was a decrease in the concentrations of these ions.

\section{Discussion}

When the plant growth medium is saline, replenishment of organic matter is important in improving the sorption capacity and soil structure. The positive effect of organic substrates on the growth of numerous plants is well documented (Marosz, 2012). Positive correlation between soil organic matter content and B adsorption has also been found (Hue et al., 1988). Application of organic matter in this experiment increased the sorption capacity of the growth medium; these results are consistent with ours (Table 3), in which $\mathrm{Na}^{+}$and $\mathrm{B}$ decreased markedly in roots with $6 \% \mathrm{OM}$ in the soil, and there was also a marked decrease in the concentration of B in leaves. The results presented here are consistent with those reported by Yermiyahu et al., (2001), which indicate that OM plays an important role in controlling B concentration in the soil solution, and that it has a prominent effect in reducing $\mathrm{B}$ uptake by plants. The $\mathrm{Na}^{+}$in roots was also decreased by the application of $6 \% \mathrm{OM}$; this prevents root from salt injuries and roots can grow as shown in Table 2 (Clark et al., 2007). These results are also in agreement with Yang et al. (2004) and Shaaban et al. (2013). This may be associated with the enhancement of biological activity in the crop rhizosphere by some physiologically active substance in the OM. Wu and Wang (2012) reported that $\mathrm{OM}$ also decreased the sodium absorption ratio (SAR), indicating the migration of exchangeable $\mathrm{Na}^{+}$from the top soil layer and accumulation in lower depths with application of OM. The $\mathrm{K}^{+}$ and $\mathrm{Ca}^{2+}$ concentrations in leaf were maintained or increased under OM treatments (Table 3). Our results are also in agreement with Ali and Abbas (2003) and Muhammad and Khattak (2011), that $\mathrm{OM}$ increases the amount of soluble $\mathrm{Ca}^{2+}$ for soil reclamation. Application of a combination of $\mathrm{OM}$ and mineral fertilizer may induce an increase in the humus content, nitrogen, and available phosphorus and potassium levels (Gondek and Filipek-Mazur, 2005). Moreover, a previous study showed that cv. "Poncho Negro" increases leaf $\mathrm{K}^{+}$, which increases or maintains leaf turgor under stress conditions (Díaz et al., 2011). In addition, the ability to maintain $\mathrm{K}^{+}$homeostasis during salt stress is considered a characteristic of better salt tolerance (Hauser and Horie, 2010).

As mentioned above, addition of OM can favour the growth of both the roots and aerial parts of the plant (Chen and Aviad, 1990; Verlinden et al., 2009); this is confirmed by the results shown in Table 2, where total plant dry weight was sustained to a greater degree, maintaining levels of compatible 
Table 3. Effects of organic matter $(\mathrm{OM})$ in individual and combined treatments of $150 \mathrm{mM} \mathrm{NaCl}$ and

B excess (20 $\left.\mathrm{mg} \mathrm{L}^{1}\right)$ on concentrations of ions of leaf tissue (a) and root tissue (b) of the tomato plant.

Values represent the mean of six samples $\pm \mathrm{SE}$. Values in a column with the same letter are not

significantly different according to the LSD at $\mathrm{P}<0.05$ using Duncan's multiple-range test.

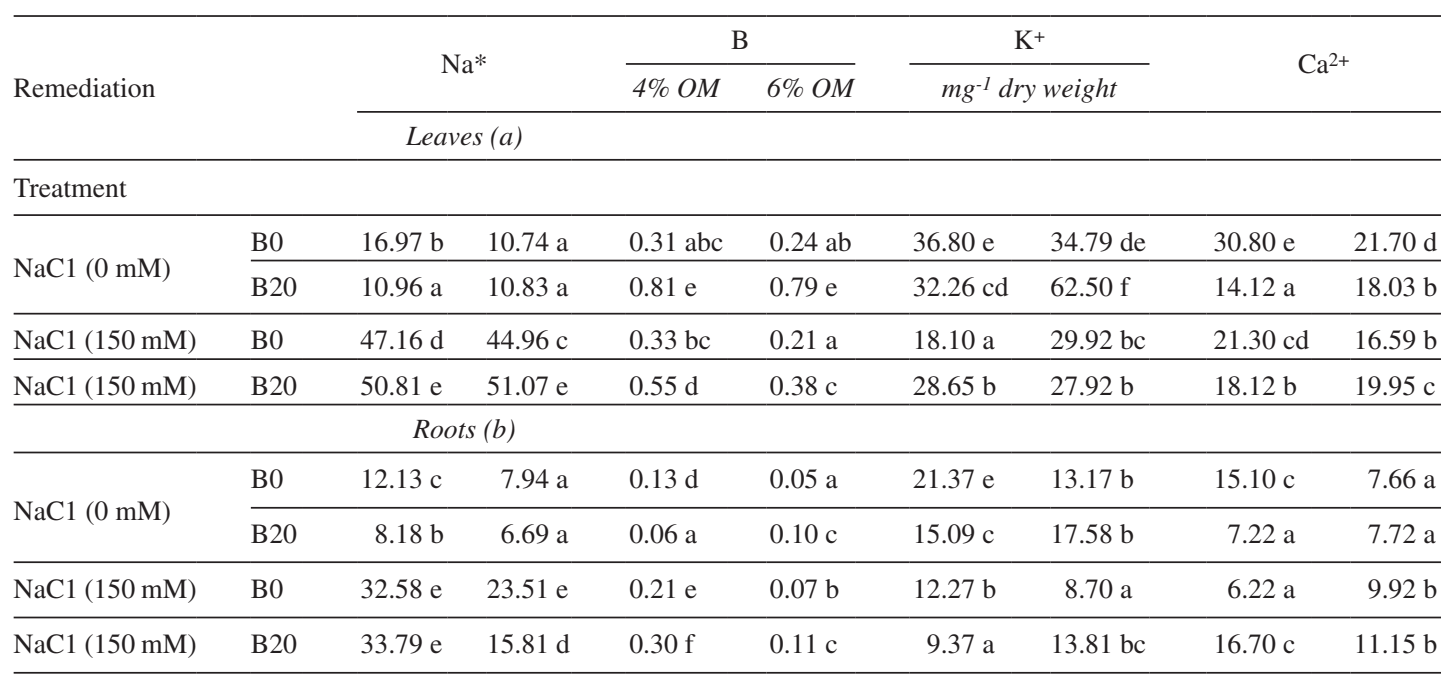

solutes such as the content of soluble sugars and proline in soil in all treatments. The most serious cause of yield reduction in crops grown in saline paddy fields that have not undergone remediation are the subsequent effects of toxic ion accumulation in the plant cell, which causes pigment reduction, diminishes chlorophyll $a$ and lowers $A$ (Cha-um and Kirdmanee, 2011). However, in the present study $A$ was effectively alleviated with $6 \% \mathrm{OM}$ in soil in treatments with excess of B and with salt alone (Figure 1), similar to the control plants. The level of total chlorophyll pigments in Poncho Negro tomato decreased in saline conditions and B excess; this level was maintained better with OM. In Hordeum maritimum and rice cv. RD6 total chlorophyll pigment levels were also maintained better with the application of OM (Lakhdar et al., 2008; Cha-um and Kirdmanee, 2011). Organic matter may contain salt ion-binding agents which detoxify the toxic ions, especially $\mathrm{Na}^{+}$and $\mathrm{Cl}^{-}$, as indicated by low EC in treated soil (Tejada et al., 2006; Zahid and Niazi, 2006).

Plants produce osmotically active solutes such as proline in response to salt stress that balance the water potential of the cytosol with the apoplast and vacuolar lumen (Szabados and Savoure, 2010). A recent study indicated a strong role of arbuscular mycorrhizal symbiosis in enhancing stress tolerance in chickpea by significantly modulating proline metabolism and $\mathrm{Na}^{+}$uptake (Garg and Baher, 2013). The functions of other compatible solutes such as glucose and sucrose include osmotic adjustment, carbon storage and radical scavenging (Parida et al., 2002). Previous studies reported high levels of soluble sugar and proline accumulated in leaves of "Poncho Negro" tomato plants grown under salinity and excess B, but the increase was different depending on the salinity and B treatment (Contreras et al., 2011; Díaz et al., 2011). In the present study the application of OM in soil changed the behaviour of plants, maintaining similar levels of both solutes compared to the control. This could be attributed to the role organic matter plays in controlling B concentration in the soil solution, since it has a prominent effect in reducing B uptake by plants in saline or non-saline conditions (Yermiyahu et al., 2001). Our results showed an increase of these compatible solutes in the treatment with only salinity with a lower percentage of organic matter $(4 \%)$; however, with the higher percentage $(6 \%)$ the levels of both solutes decreased markedly, similar to the levels observed in control plants. This behaviour is an interesting point that could explain the increase in biomass under saline conditions, as the plant spent the extra metabolic energy in the synthesis of proline and soluble sugars.

In summary, the present and previous studies show that the "Poncho Negro" variety is able 
to adjust osmotically by increasing turgor, and no toxic effects of salinity and excess of B were observed (Contreras et al., 2011; Díaz et al., 2011). Masood et al., (2012) concluded that the effects of salt are different at different levels of B supply. With an adequate B supply, salt increases soluble B concentrations, whereas under excessive B supply B concentrations are reduced. In the "Poncho Negro" tomato, B concentration increased both in leaf and root with excessive B (Table 3 ) under salinity. It is suggested that combined salt and B excess produced an alleviating effect, which did increase growth (Table 2). Maintenance of the net photosynthetic rate $(A)$ in the salt-stressed and excess of B leaves was strongly related to increase in total dry weight, by the decrease in the concentration of $\mathrm{B}$ and $\mathrm{Na}^{+}$in both leaf and as root, maintaining levels of compatible solutes such as the content of soluble sugars and proline, thus the application of $6 \% \mathrm{OM}$ treatment in soil could effectively alleviate the problem of stress, resulting in behaviour improvement of "Poncho Negro" tomato. All these results show that cv. "Poncho Negro" from the Lluta valley (northern Chile), is a germplasm with agronomic interest and which yields well in the field. This study demonstrates the potential use of $6 \%$ of $\mathrm{OM}$ in soil with saline and excess of $\mathrm{B}$ conditions for managing crops that are subjected to stresses, with the improvement of soil properties mitigating salinity or other specific ions with organic amendments.

\section{Conclusion}

We conclude that maintaining $6 \% \mathrm{OM}$ in soil with saline and excess of $\mathrm{B}$ is an appropriate condition for managing crops that are subjected to these stresses, along with improvement of soil properties mitigating salinity or other specific ions with organic amendments.

\section{Acknowledgements}

This study was funded partly by Project UTAMayor 9721-13 and Project FIC P117 Código BIP 30158423-0 and Convenio de Desempeño Educación Superior Regional UTA-1401(Arica-Chile).

\section{Literature Cited}

Ali, R.M.; Abbas, H.M.

2003. Response of salt stressed barley seedlings to phenylurea. Plant Soil and Environmental, 49: 158-162.

Al-Rawahy, S.A.; Stroehlein, J.L.; Pessarakli, M.

1990. Effect of salt stress on dry matter production and nitrogen uptake by tomatoes 1. Journal of Plant Nutrition, 13: 567-577.

Bastías, E.; Alcaraz-López, C.; Bonilla, I.; Martínez-Ballesta, M.C.; Bolaños, L.; Carvajal M.

2010. Interactions between salinity and boron toxicity in tomato plants involve apoplastic calcium. Journal Plant Physiology 167: 54-60.

Bastías, E.; González-Moro, M.B.; Gozález-Murua, C. 2004. Zea mays L. Amylacea from the Lluta Valley (AricaChile) tolerate salinity stress when high levels of boron are available. Plant and Soil, 267: 73-84.

Bates, L.S.

1973. Rapid determination of free proline for water stress studies. Plant and Soil 39: 205-207.

Bonilla, I.; González-Fontes, A.

2011. Salt Stress in Vascular Plants and Its Interaction with Boron Toxicity, Plants and Environment, Hemanth KN. Vasanthaiah and Devaiah Kambiranda (Ed.), ISBN: 978-953307-779-6, 227-240 p. InTech, Available from: http://www. intechopen.com/books/plants-and-environment/salt-stressin-vascular-plants-and-its-interaction-with-boron-toxicity.

Cha-um, S.; Kirdmanee, C.

2011. Remediation of salt-affected soil by the addition of organic matter: an investigation into improving glutinous rice productivity. Scientia Agricola, 68: 406-410.
Chen, Y.; Aviad, T.

1990. Effects of humic substances on plant growth. Humic substances in soil and crop sciences: Selected Readings, (Humicsubstances), 1: 161-186.

Clark, G.J.; Dodgshun, N.; Sale, P.W.G.; Tang, C.

2007. Changes in chemical and biological properties of a sodic clay subsoil with addition of organic amendments. Soil Biology and Biochemistry, 39: 2806-2817.

Contreras, C.; Montoya, A.; Pacheco, P.; Martínez-Ballesta, M.C.; Carvajal, M.; Bastías, E.

2011. The effects of the combination of salinity and excess boron on the water relations of tolerant tomato (Solanum lycopersicum L.) cv. Poncho Negro, in relation to aquaporin functionality. Spanish Journal of Agricultural Research, 9: 494-503.

Díaz, M.; Bastías, E.; Pacheco, P.; Tapia, L.; Martínez-Ballesta, M.C.; Carvajal, M.

2011. Characterization of the physiological response of the highly-tolerant tomato cv. 'Poncho Negro' to salinity and excess boron. Journal of Plant Nutrition, 34: 1254-1267.

Doganler, Z.B.; Demir, K.; Basak, H.; Gul, I.

2010. Effect of Salt Stress on Pigment and Total Soluble Protein Con-tents of Three Different Tomato Cultivars. African Journal of Agricultural Research, 5: 2056-2065.

Garg, N.; Baher, N.

2013. Role of Arbuscular Mycorrhizal Symbiosis in Proline biosynthesis and Metabolism of Cicer arietinum L. (Chickpea) Genotypes under Salt Stress. Journal of Plant Growth Regulation, 32: 767-778. 
Ghafoor, A.; Murtaza, G.; Ahmad, B.; Boers, Th.M.

2008. Evaluation of amelioration treatments and economic aspects of using saline-sodic water for rice and wheat production on salt-affected soils under arid land conditions. Irrigation and Drainage, 57: 424-434.

Gondek, K.; Filipek-Mazur, B.

2005. The effects of mineral treatment and the amendments by organic and organ mineral fertilizers on the crop yield, plant nutrient status and soil properties. Plant Soil and Environmental, 51: 34-45.

Hauser, F.; Horie, T.

2010. A conserved primary salt tolerance mechanism mediated by HKT transporters: a mechanism for sodium exclusion and maintenance of high $\mathrm{K}+/ \mathrm{Na}+$ ratio in leaves during salinity stress. Plant, Cell and Environment, 33: 552-565.

Herrera-Rodríguez, M.B.; González-Fontes, A.; Rexach J.; Camacho-Cristóbal, J.J.; Maldonado, J.M.; NavarroGochicoa, M.T.

2010. Role of boron in vascular plants and response mechanisms to boron stresses. Plant Stress, 4: 115-122.

Hue, N.; Hirunburana, N.; Fox R.

1988. Boron status of Hawaiian soils as measured by B sorption and plant uptake. Communication Soil Science and Plant Analysis, 19: 517-528.

Irigoyen, J.J.; Einerich, D.W.; Sánchez-Díaz, M.

1992. Water stress induced changes in concentrations of proline and total soluble sugars in nodulated alfalfa (Medicago sativa) plants. Physiology Plantarum 84: 55-60.

Lakhdar, A.; Hafsi, C.; Rabhi, M.; Debez, A.; Montemurro, F.;

Abdelly, C.; Jedidi, N.; Ouerghi, Z.

2008. Application of municipal solid waste compost reduces the negative effects of saline water in Hordeum maritimum L. Bioresource Technolohy 99: 7160-7167.

Maggio, A.; Barbieri, G.; Raimondi, G.; De Pascale, S.

2010. Contrasting effects of $\mathrm{GA}_{3}$ treatments on tomato plants exposed to increasing salinity. Journal Plant Growth Regulation 29: 63-72.

Marosz, A.

2012. Effect of green waste compost and mycorrhizal fungi on calcium, potassium, and sodium uptake of woody plants grown under salt stress. Water, Air, \& Soil Pollution, 223: 787-800.

Masood, S.; Wimmer, M.A.; Witzel, K.; Zörb, C.; Mühling, K.H. 2012. Interactive effects of high boron and $\mathrm{NaCl}$ stresses on subcellular localization of chloride and boron in wheat leaves. Journal of Agronomy and Crop Science, 198: 227-235.

Matt, J.K.; Chuah, H.H.; Neufeld, J.H.

1975. Applications of improved Azoinethine-H method in the etermination of boron in soils and plants. Analytical Letters 8: 559-568.

Muhammad, D.O.S.T.; Khattak R.A.

2011. Wheat yield and chemical composition as influenced by integrated use of gypsum, pressmud and FYM in salinesodic soil. Journal of the Chemical Society of Pakistan, 33: 82-86.

Parida, A.; Das, A.B.; Das, P.

2002. $\mathrm{NaCl}$ stress causes changes in photosynthetic pigments, proteins and other metabolic components in the leaves of a true mangrove, Bruguiera parviflora, in hydroponic cultures. Journal Plant Biology 45: 28-36.
Rajaravindran, M.; Natarajan, S.

2012. Effects of salinity stress on growth and antioxidant enzymes of the halophyte Sesuvium portulacastrum. International Journal Research Plant Science, 2: 23-28.

Reid, R.; Hayes, J.; Post, A.; Stangoulis, J.; Graham, R.

2004. A critical analysis of the cause of boron toxicity in plants. Plant Cell and Environmental 27: 1405-1414.

Shaaban, M.; Abid, M.; Abou-Shanab, R.A.I.

2013. Amelioration of salt affected soils in rice paddy system by application of organic and inorganic amendments. Plant Soil and Environment, 59: 227-233.

Szabados, L.; Savouré, A.

2010. Proline: a multifunctional amino acid. Trends in Plant Science 15: 89-97.

Tejada, M.; García, C.; González, J.L.; Hernández, M.T.

2006. Use of organic amendment as a strategy for saline soil remediation: influence on the physical, chemical and biological properties of soil. Soil Biology and Biochemistry, 38: 1413-1421.

Tuna, A.L.; Kaya, C.; Ashraf, M.; Altunlu, H.; Yokas, I.; Yagmur, B. 2007. The effects of calcium sulphate on growth, membrane stability and nutrient uptake of tomato plants grown under salt stress. Environmental and Experimental Botany, 59: 173-178.

Uozumi, A.; Ikeda, H.; Hiraga, M.; Kanno, H.; Nanzyo, M.;

Nishiyama, M.; Kanayama, Y.

2012. Tolerance to salt stress and blossom-end rot in an introgression line, IL8-3, of tomato. Scientia Horticulturae, 138: $1-6$.

Verlinden, G.; Pycke, B.; Mertens, J.; Debersaques, F.; Ver-heyen, K.; Baert, G.; Bries, J.; Haesaert, G.

2009. Application of humic substances results in consistent increases in crop yield and nutrient uptake. Journal of Plant Nutrition, 32: 1407-1426.

Weimberg R.

1987. Solute adjustments in leaves of two species of wheat at two different stages of growth in response to salinity. Physiologia Plantarum, 70: 381-388.

Wong, V.N.; Dalal, R.C.; Greene, R.S.

2009. Carbon dynamics of sodic and saline soils following gypsum and organic material additions: a laboratory incubation. Applied Soil Ecology, 41: 29-40.

Wu, G.Q.; Wang, S.M.

2012. Calcium regulates $\mathrm{K}^{+} / \mathrm{Na}^{+}$homeostasis in rice (Oryza sativa L.) under saline conditions. Plant Soil and Environmental, 58: 121-127.

Yang, C.; Yang, L.; Yang, Y.; Ouyang, Z.

2004. Rice root growth and nutrient uptake as influenced by organic manure in continuously and alternately flooded paddy soils. Agricultural Water Management, 70: 67-81.

Yang, G.; Zhou, R.; Tang, T.; Chen, X.; Ouyang, J.; He, L.; Li, W.; Chen, S.; Guo, M.; Li, X.; Zhong, C.; Shi, S.

2011. Gene Expression Profiles in Response to Salt Stress in Hibiscus Tiliaceus. Molecular Biology Reporter, 29: 609-617.

Yermiyahu, U.; Keren, R.; Chen, Y.

2001. Effect of composted organic matter on boron uptake by plants. Soil Science Society of America Journal, 65: 1436-1441.

Zahid, L.; Niazi, M.F.K.

2006. Role of ristech material in the reclamation of salinesodic soils. Pakistan Journal of Water Resources 10: 43-49. 